\title{
Femtosecond-assisted intrastromal corneal ring implantation for keratoconus treatment: a comparison with crosslinking combination
}

\author{
Implante de anel intraestromal com laser de femtosegundo no tratamento de ceratocone: \\ comparação da combinação com o crosslinking
}

Peter Alexander von Harbach Ferenczy ${ }^{1}$, Maiara Dalcegio ${ }^{1}$, Marcela Koemler ${ }^{2}$, Thiago Silveira Pereira², Hamilton Moreira ${ }^{3}$, Luciane Bugmann Moreira ${ }^{4}$

\begin{abstract}
Purpose: To compare visual outcomes, corneal astigmatism, and keratometric readings in patients with keratoconus who underwent intrastromal corneal ring implantation (ICRSI) alone with those who underwent ICRSI combined with ultraviolet A riboflavin-mediated corneal collagen crosslinking (CXL).

Methods: Pre- and post-operative best-corrected distance visual acuity (BCDVA), spherical error, cylindrical error, and mean keratometry were retrospectively compared over a period of 2 years in patients with keratoconus who underwent only ICRSI (group 1) versus those in patients who underwent combined ICRSI-CXL (group 2). Results: Thirty-two eyes of 31 patients were evaluated. CXL was performed in 10 cases $(31 \%)$, and there were no complications or need for ring repositioning. BCDVA improved from 0.54 to 0.18 in the group 1 and from 0.56 to 0.17 in the group 2. Spherical and cylindrical errors and mean keratometry values significantly decreased in both groups. No patient postoperatively had visual acuity (VA) of less than $20 / 60$ on refraction, and $78 \%$ exhibited VA better than or equal to $20 / 40$ with spectacles (72\% of group 1 and $90 \%$ of group 2). Improvement in the spherical equivalent (SE) value was observed in the group 1 (from $-5.89 \pm 3.37$ preoperatively to $-2.65 \pm 2.65$ postoperatively; $p<0.05$ ) and group 2 (from $-6.91 \pm$ 1.93 preoperatively to $-2.11 \pm 3.01$ postoperatively; $p<0.05$ ).

Conclusion: Both techniques can be considered safe and effective in improving VA and refractive SE values, in decreasing the curvature of the cone apex in the topographical analysis, and in decreasing corrected diopters postoperatively in patients with keratoconus.
\end{abstract}

Keywords: Cornea; Corneal stroma; Keratoconus; Prosthesis implantation; Crosslinking reagents; Riboflavin/therapeutic use; Ultraviolet rays; Visual acuity

\section{RESUMO}

Objetivo: Comparar os resultados visuais, astigmatismo corneano e ceratometria em pacientes com ceratocone submetidos a implante de anel corneano intraestromal (ICRSI) e quando em combinação com radiação ultravioleta associado ao crosslinking do colágeno corneano mediada pela riboflavina (CXL).

Métodos: Comparou-se retrospectivamente pacientes com ceratocone submetidos somente a implante de anel corneano intraestromal (grupo 1) versus o mesmo procedimento associado ao crosslinking em um período de 2 anos. Avaliou-se acuidade visual com correção, equivalente esférico, ápice do cone na topografia e adaptação com lentes de contato pré e pós operatórios.

Resultados: O estudo avaliou 32 olhos de 31 pacientes. Em 10 casos (31\%) foi realizado crosslinking corneano, não havendo complicações ou necessidade de reposicionamento do anel. Acuidade visual corrigida pré e pós-operatória, componentes esférico e cilíndrico da refração e valores de ceratometria media diminuíram significativamente em ambos os grupos. Após o implante, nenhum paciente apresentou acuidade visual pior que 20/60 e 78\% apresentaram acuidade corrigida melhor ou igual a 20/40 (72\% do grupo 1 e 90\% do grupo 2). Observou-se diminuição no valor do equivalente esférico no grupo 1 (de -5,89 $\pm 3,37$ pré-operatório para-2,65 $\pm 2,65$ pós-operatório; $p<0,05)$ e no grupo 2 (de $-6,91 \pm 1,93$ pré-operatório para $-2,11 \pm$ 3,01 pós-operatório; $p<0,05)$.

Conclusão: Ambas as técnicas podem ser consideradas seguras e eficazes na melhora da acuidade visual e equivalente esférico, diminuição do ápice de curvatura do cone na análise topográfica e na redução de dioptrias a serem corrigidas no pós-operatório de pacientes com ceratocone.

Descritores: Córnea; Substância própria; Ceratocone; Implantedeprótese; Reagentes paralicações cruzadas; Riboflavina/uso terapêutico; Raiosultravioleta; Acuidadevisual

\section{INTRODUCTION}

Keratoconus is a non-inflammatory ectatic corneal disorder. It is characterized by paracentral corneal thinning and increased corneal curvature leading to irregular astigmatism, myopia, and protrusion ${ }^{(1)}$. Initial treatment includes using spectacles and rigid contact lenses. Several surgical procedures, such as corneal transplantation, epikeratophakia, and photorefractive keratectomy, have been developed for more advanced cases; however, some of these have yielded disappointing results $s^{(2-4)}$.
Intrastromal corneal ring segments (ICRS) are an interesting alternative for keratoconus treatment in patients with clear corneas and contact lens intolerance ${ }^{(5-7)}$. There are several different models with varying sizes and arch thicknesses. These segments induce an arch shortening effect in the lamella leading to central flattening of the cornea. The main advantages of this procedure are its safety, reversibility, and stability as well as the fact that segments do not affect the corneal visual axis(8-13). The intrastromal tunnel for ring implantation was initially manually constructed; however, complica-
Submitted for publication: September 11, 2014

Accepted for publication: January 19, 2015

Anterior Segment Sector, Hospital de Olhos do Paraná, Curitiba, PR, Brazil.

Refractive Surgery Sector, Hospital de Olhos do Paraná, Curitiba, PR, Brazil.

3 Hospital de Olhos do Paraná, Curitiba, PR, Brazil.

${ }^{4}$ Contact Lens Sector, Hospital de Olhos do Paraná, Curitiba, PR, Brazil.
Funding: No specific financial support was available for this study.

Disclosure of potential conflicts of interest: None of the authors have any potential conflict of interest to disclose.

Corresponding author: Peter Alexander von Harbach Ferenczy. Alameda Presidente Taunay, 483 Curitiba, PR - 80420-180 - Brazil - E-mail: ferenczypeter@yahoo.com.br

Approved by the following research ethics committee: Universidade Positivo: number 465.316 date: November 22, 2013 
tions, such as epithelial defects, depth asymmetry, and perforation, were reported ${ }^{(5,6,13)}$.

Femtosecond laser has recently been used to create the tunnel for ring implantation. This technique reportedly creates a tunnel with precise depth, width, and location leading to minimal haze and edema as well as minimal surgical complications. The laser acts via photodisruption and can be programed to create tunnels for segment placement at predetermined depths. Studies have shown that tunnel creation using this technique is easier, more precise, and more predictable than the technique involving a conventional mechanical microkeratome ${ }^{(7)}$.

We studied the outcomes of patients with keratoconus who underwent intrastromal corneal ring implantation (ICRSI) using femtosecond laser (Ziemer LDV) at the Hospital de Olhos do Paraná. Our aim was to evaluate the visual improvement in these patients, the safety of this technique, and the differences between ICRSI alone and its combination with postoperative ultraviolet A riboflavin-mediated corneal collagen crosslinking $(\mathrm{CXL})$ procedure.

\section{METHODS}

This was an observational study approved by the Research Ethics Committee of Positivo University on November 22, 2013 under the protocol number 465.316.

The medical records of patients with keratoconus seen at Hospital de Olhos do Paraná who underwent ICRSI using femtosecond laser or who had ICRSI combined with CXL were retrospectively analyzed. The medical records from January 2011 to December 2012 were reviewed, and the time of the follow-up that was considered for the analysis was from 6-15 months.

The inclusion criteria were as follows: (1) eyes with keratoconus in the topographical analysis confirmed by two experienced ophthalmologists; (2) presence of the clear central cornea; (3) corrected visual acuity (VA) of less than 20/40 according to the Snellen chart; (4) intolerance to contact lenses or no improvement in VA with contact lenses; (5) a minimum central corneal thickness of $380 \mu$ and a minimum corneal thickness of $400 \mu$ at the site of the incision and construction of the corneal tunnel for ring implants; and (6) a minimum central corneal thickness of $400 \mu$ for the CXL procedure.

The exclusion criteria were as follows: (1) incomplete clinical data in the medical records; (2) loss to follow-up of patients 3 months postoperatively; (3) history of eye diseases such as glaucoma, cataract, diabetic retinopathy, and age-related macular disease; (4) preoperative plano spherical equivalent (SE); (5) history of eye surgery; and (6) collagen disease or pregnancy.

In this study, ICRSI (CornealRing, Visiontech ${ }^{\circledR}$, Belo Horizonte, Brazil) was performed by two experienced surgeons using the femtosecond laser (Ziemer LDV, Ziemer Ophthalmic Systems, Switzerland) to create the stromal tunnel. The channel's inner diameter was set to $4.8 \mathrm{~mm}$ and the outer diameter was set between 6.02 to $6.26 \mathrm{~mm}$; the entry cut thickness was set to $1.3 \mathrm{~mm}$ and 10 degrees in length (at the steepest topographical axis), the velocity for was set for $3.2 \mathrm{~mm} / \mathrm{s}$, $1.0 \mathrm{~mm} / \mathrm{s}$ and $5.2 \mathrm{~mm} / \mathrm{s}$ for the stroma, vertical incision and insertion, respectively. The power was set at 100\% for the stroma and at 150\% for the vertical incision. A vacuum setting at 750 mbar on controlled mode with automatic release mode was applied. The nomogram is available online at www.cornealring.com.

The selected clinical and topographical data were assessed preand postoperatively. The clinical examination data included the best spectacle-corrected VA, spherical and cylindrical diopter values, and SE. The topographical data included the maximum, minimum, and mean keratometric values (Kmax, Kmin, and Kmed, respectively) as well as the corneal apex value in diopters (D). In addition, the information on the transoperative and postoperative complications and on the performance of the corneal crosslinking was considered.
The differences in VA and topographical data between pre- and post-ICRSI period as well as the perioperative and postoperative complications were assessed during the study period.

CXL was performed on eyes that showed evidence of ectasia and that still had Iow VA 3 months after ICRSI. Ectasia was considered if the topography showed at least $0.5 \mathrm{D}$ of progression in the corneal curvature index over a 6-month period.

After central corneal abrasion in the operating room and under appropriate sterile conditions, $0.5 \%$ proparacaine hydrochloride drops were used as local anesthesia. The central corneal epithelium was removed $(9 \mathrm{~mm})$ with a blunt spatula. A photosynthetic riboflavin $0.1 \%$ solution $(10 \mathrm{mg}$ riboflavin- 5 -phosphate in $10 \mathrm{~mL}$ of dextran T-500 20\%), was applied to the cornea every 5 min for 30 min before the ultraviolet $A$ (UVA) irradiation.

The cornea was then exposed to UVA irradiation with a solid state device: the X-Link (Opto Electronics, San Carlos, Brazil), which emitted light at a wavelength of $370 \pm 5 \mathrm{~nm}$ at an irradiance of $3 \mathrm{~mW} / \mathrm{cm}^{2}$ or $5.4 \mathrm{~J} / \mathrm{cm}^{2}$. The corneal exposure lasted $30 \mathrm{~min}$, while the riboflavin solution was applied every 5 min.

The data were described as the mean, median, minimum and maximum values, and standard deviations. The preoperative comparisons were performed using Student's t-test for independent samples. The postoperative comparisons and differences between pre- and postoperative values were based on the model analysis of covariance (ANCOVA), including the preoperative evaluation as a covariate. To compare the pre- and post-ratings within each treatment, we used Student's t-test for paired samples; for variable VA logMAR comparisons, we used the nonparametric Mann-Whitney test. Comparisons between pre- and postoperative values within each group were made utilizing the non-parametric Wilcoxon test. $P$ values of $<0.05$ were considered statistically significant. The normal variables were evaluated by the Kolmogorov-Smirnov test. All analyses were performed using IBM SPSS Statistics v.20.

\section{RESULTS}

Thirty-one patients with keratoconus who underwent ICRSI using femtosecond laser (32 eyes) were studied. The group 1 consisted of 14 (63\%) men and eight (37\%) women with ages between 16 and 52 years (mean $28.9 \pm 8.2$ years). The group 2 consisted of seven (70\%) men and three (30\%) women with ages between 19 and 37 years (mean, $27 \pm 6.4$ ).

Except for the mean $\mathrm{K}(p=0.02)$, all other preoperative variables were similar between the two groups (age: $p=0.53$; gender: $p=1$; spherical refractive error: $p=0.67$; astigmatism: $p=0.09$; corneal apex: $p=0.49$; and VA in logMAR: $p=0.76$ ), as presented in table 1 .

Table 1. Evaluation of associated factors with conus progression after ICRS

\begin{tabular}{lccc}
\hline & \multicolumn{2}{c}{ Group } & \\
\cline { 2 - 3 } Variable & ICRSI & ICRSI + CXL & P value* \\
\hline Age (years) & $28.90 \pm 8.20$ & $27.00 \pm 6.40$ & 0.529 \\
Male & $63.6 \%$ & $70.0 \%$ & 1 \\
Spheric pré & $-3.99 \pm 3.08$ & $-4.45 \pm 2.18$ & 0.674 \\
Cilindric pré & $-3.80 \pm 1.96$ & $-4.93 \pm 1.03$ & 0.098 \\
SE pré & $-5.89 \pm 3.37$ & $-6.91 \pm 1.93$ & 0.379 \\
K-average pré & $50.90 \pm 2.75$ & $47.06 \pm 2.24$ & 0.018 \\
Apex pré & $58.19 \pm 2.99$ & $56.56 \pm 4.75$ & 0.493 \\
VA logMAR & $0.54 \pm 0.24$ & $0.56 \pm 0.34$ & 0.764 \\
\hline
\end{tabular}

*Student's t-test or exact Fisher test, $p<0.05$ 
Table 2. Differences in best-corrected visual acuity between groups

\begin{tabular}{|c|c|c|c|c|c|c|c|c|}
\hline & Treatment & $\mathbf{n}$ & Mean & Median & Minimum & Maximum & Standard deviation & $P$ value \\
\hline Preoperative VA & ICRSI & 22 & 0.54 & 0.47 & 0.30 & 1.30 & 0.24 & \\
\hline $\log M A R$ & $|C R S|+C X L$ & 10 & 0.56 & 0.47 & 0.30 & 1.30 & 0.34 & 0.764 \\
\hline $\log M A R$ & $|C R S|+C X L$ & 10 & 0.17 & 0.17 & 0.09 & 0.47 & 0.11 & 0.646 \\
\hline Difference pre- and post-operative & ICRSI & 22 & 0.36 & 0.38 & -0.17 & 0.83 & 0.22 & \\
\hline
\end{tabular}

* = nonparametric Mann-Whitney test, $\mathrm{p}<0.05$

$\mathrm{VA}=$ visual acuity; ICRSI= intrastromal corneal ring implantation; $\mathrm{CXL}=$ crosslinking

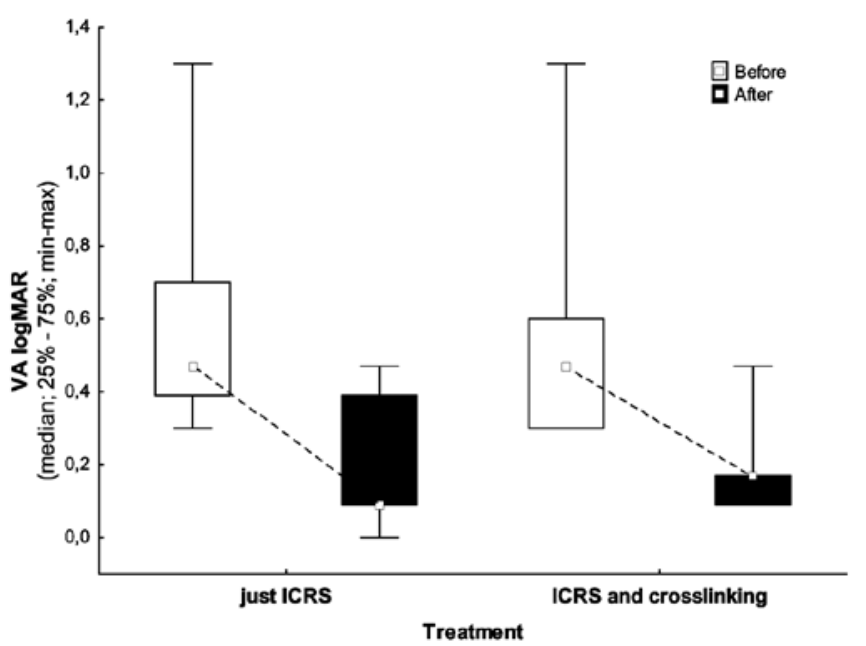

Figure 1. Pre- and postoperative VA data per groups (logMAR).

CXL was performed in 10 eyes (31\%) at a mean time of $5.8 \pm 2.04$ months after the ring insertion. In all cases in which CXL was performed, there were no complications or need for ring repositioning.

VA of patients preoperatively ranged from 20/40 to 20/400 (Snellen chart) in both groups. No patient postoperatively presented with VA worse than 20/60, and 78\% exhibited VA better than or equal to 20/40 with spectacles in both groups. Table 2 and figure 1 show differences in the best-corrected VAs before and after the procedure.

In the group 1, the spherical refraction ranged from $-9.50 \mathrm{D}$ to plano preoperatively, with a mean cylindrical value of $-3.80 \mathrm{D}$. In the group 2, the spherical refraction ranged from -7.00 to $-0.25 \mathrm{D}$ preoperatively, with a mean cylindrical value of $-4.93 \mathrm{D}$.

Postoperatively, the spherical refraction in the first group ranged from -7.00 to $+1.50 \mathrm{D}$; the mean cylindrical value was $-2.22 \mathrm{D}$. In the group 2 , the spherical refraction ranged from -7.00 to $+4.75 \mathrm{D}$, and the mean cylindrical value was -2.38 D.

The SE improved in both groups; SE improved from $-5.89 \pm 3.37$ to $-2.65 \pm 2.65(p<0.001)$ in the group 1 and from $-6.91 \pm 1.93$ to $-2.11 \pm$ 3.01 postoperatively $(p<0.001)$ in the group 2 .

Regarding the keratometric values in the pre- and postoperative topographical analyses, only one implant did not demonstrate a decreased corneal apex value. However, all other patients had an improvement in VA and SE (group 1, $p=0.001$; group 2, $p=0.01$ ). Table 3 and figure 2 show the pre- and postoperative keratometric data.

The mean $\mathrm{K}$ value of the corneal apex improved after the procedure (group 1, $p=0.001$; group 2, $p=0.007$ ), although there was no significant statistical difference between the groups (Table 4 and Figure 3).
In the group 2, when comparing the data 3 months after ICRSI, we observed statistical differences in the spherical refractions $(p=0.007)$, astigmatism ( $p=0.01)$, SEs $(p=0.002)$, corneal apices $(p=0.006)$, and VAs $(p=0.007)$ (Table 5).

\section{DISCUSSION}

The correction of irregular astigmatism caused by primary corneal ectasia is a challenging process. With advancing topographical changes, optical correction becomes ineffective, and the main treatment consists of rigid contact lenses. These provide a uniform surface that neutralizes the myopia and irregular astigmatism associated with keratoconus. When these patients become intolerant to contact lenses, even in the absence of a lesion at the ectasia apex, corneal transplantation is recommended ${ }^{(14)}$.

Several surgical procedures have been proposed as an alternative to penetrating keratoplasty for the treatment of keratoconus, such as photorefractive keratectomy, epikeratoplasty, sectorial keratectomy, and lamellar keratoplasty; however, some of these have yielded disappointing results ${ }^{(2-4)}$. The deep lamellar keratoplasty and penetrating keratoplasty procedures have considerably improved in recent years ${ }^{(15,16)}$. The best spectacle-corrected VA, refractive results, and complication rates have been similar for both techniques, although the nature of complications varied depending on the technique. Deep lamellar keratoplasty is technically more challenging than penetrating keratoplasty; however, it prevents endothelial rejection and may reduce the risk for late endothelial failure ${ }^{(15)}$. Despite its complications, such as the side effects of corticosteroids and allogeneic reactions, the success rate of penetrating keratoplasty is $93 \%-96 \%{ }^{(17,18)}$.

In 2000, Colin et al. ${ }^{(19)}$ described their preliminary results for keratoconus management using ICRSI. Since then, several studies have shown that this was a safe procedure for the correction of corneal ectasias and astigmatism using the manual tunnel dissection technique ${ }^{(19-22)}$. However, several complications related to the manual dissection technique have been observed: epithelial defects, anterior and posterior corneal perforation, superficial placement and displacement of the segment, stromal thinning, extension of the incision to the center of the cornea or close to the limbus, infectious keratitis due to the introduction of epithelial cells in the tunnel, extrusion of the segment, and stromal edema around the tunnel ${ }^{(23,24)}$. Rabinowitz et al. ${ }^{(25)}$ observed epithelial defects in $50 \%$ of patients when using the manual tunnel dissection technique.

A small amount of long-term data is available for ICRS placement, and any effect of ICRSI on disease progression remains uncertain. In a case series of Intacs ICRSI with 3-year follow-up in 13 eyes, significant increases in the average $K$ values were observed between 6 months and 3 years, indicating that disease stabilization was not achieved by ICRSI alone ${ }^{(8)}$.

Intacs alone may not stop progressive keratoconus. Alió et al. ${ }^{(8)}$ found a 1.67 D rise in mean $\mathrm{K}$ values between 6 months and 36 months in a series of 13 eyes after ICRSI. This was expected, particularly in 
Table 3. Differences in mean keratometric data between groups

\begin{tabular}{|c|c|c|c|c|c|c|c|c|}
\hline & Treatment & $\mathbf{n}$ & Mean & Median & Minimum & Maximum & Standard deviation & $P$ value \\
\hline \multirow[t]{2}{*}{ Mean K pre } & ICRSI & 13 & 50.90 & 50.89 & 47.34 & 55.74 & 2.75 & \\
\hline & $|C R S|+C X L$ & 7 & 47.06 & 47.15 & 42.61 & 49.72 & 2.24 & $0.018^{*}$ \\
\hline Mean K post & $|C R S|+C X L$ & 7 & 44.50 & 45.61 & 42.03 & 46.05 & 1.78 & $0.768^{* *}$ \\
\hline \multirow[t]{2}{*}{ Difference pre and post } & $|C R S|$ & 13 & 3.78 & 3.99 & -2.29 & 6.27 & 2.10 & \\
\hline & $|C R S|+C X L$ & 7 & 2.56 & 2.45 & 0.41 & 5.16 & 1.85 & $0.768^{* *}$ \\
\hline
\end{tabular}

${ }^{*}=$ Student's t-test for independent samples, $p<0.05 ;{ }^{* *}=$ ANCOVA.

$\mathrm{VA}=$ visual acuity; $I C R S I=$ intrastromal corneal ring implantation; $C X L=$ crosslinking.

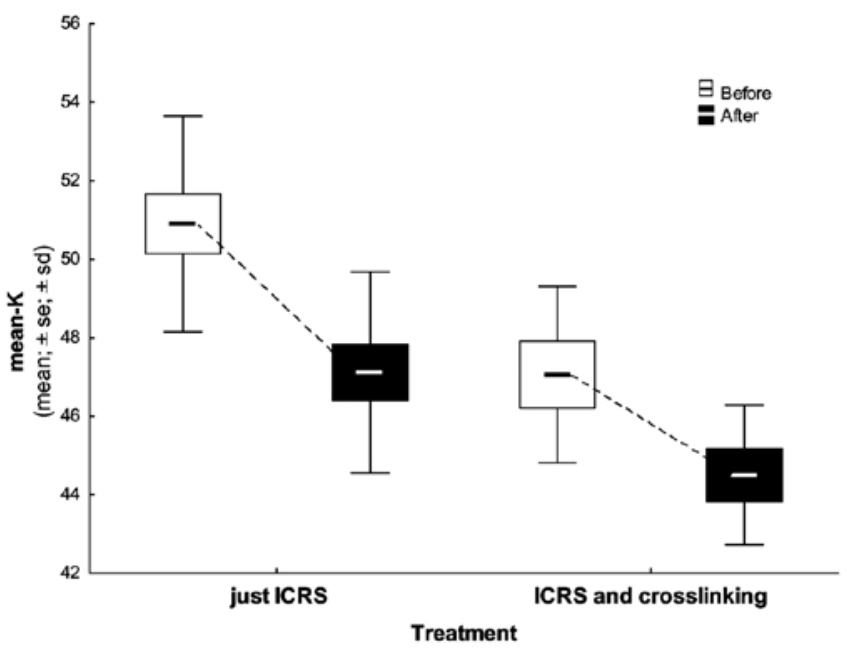

se $=$ standard error; $\mathrm{sd}=$ standard deviation.

Figure 2. Pre and postoperative mean $\mathrm{K}$ data per groups (diopters).

Table 4. Differences in corneal apex between groups

\begin{tabular}{|c|c|c|c|c|c|c|c|c|}
\hline & Treatment & $n$ & Mean & Median & Minimum & Maximum & Standard deviation & $P$ value \\
\hline \multirow[t]{2}{*}{ Apex pre } & ICRSI & 13 & 58.19 & 58.18 & 53.03 & 63.40 & 2.99 & \\
\hline & $I C R S I+C X L$ & 7 & 56.65 & 57.72 & 48.06 & 62.43 & 4.75 & $0.493^{*}$ \\
\hline Apex post & $\mid C R S I+C X L$ & 7 & 51.06 & 51.49 & 47.53 & 55.11 & 2.62 & $0.309^{* *}$ \\
\hline \multirow[t]{2}{*}{ Difference pre and post } & ICRSI & 13 & 4.63 & 5.46 & -6.59 & 8.35 & 3.66 & \\
\hline & $|C R S|+C X L$ & 7 & 5.59 & 6.23 & -1.38 & 10.43 & 3.67 & $0.309^{* *}$ \\
\hline
\end{tabular}

${ }^{*}=$ Student's t-test for independent samples, $p<0.05 ;{ }^{* *}=$ ANCOVA.

$\mathrm{VA}=$ visual acuity; $\mid \mathrm{CRSI}=$ intrastromal corneal ring implantation; $\mathrm{CXL}=$ crosslinking.

cases of rapidly-progressing keratoconus, because the ring insertion does not treat the underlying structural issue of the weakened collagen. Therefore, combining CXL with ICRS insertion in patients with progressive keratoconus is an attempt to ensure stability. It has been proven that $C X L$, unlike ring insertion, increased the biomechanical rigidity by 4.5 -fold. In addition to the crosslinking of the collagen lamellae, the collagen fibril diameter also increases ${ }^{(26)}$.

The literature has not shown significant differences between refractive outcomes among different models with same shapes and sizes for ICRS. Haddad et al. compared Intacs SK ICRS and Keraring SI6 ICRS; both ICRS models significantly improved the visual function in patients with keratoconus with comparable postoperative profiles and no major complications ${ }^{(27)}$.

The first clinical result on the use of femtosecond laser for tunnel creation was reported in 2003 by Ratkay-Traub et al. ${ }^{(28)}$. They evaluated a limited series of 16 eyes and obtained refractive results similar to those observed in patients who had the tunnel constructed manually. Others have also reported a significant improvement in corrected and uncorrected VA and in keratometric values after ICRSI using femtosecond laser ${ }^{(25,29,30)}$. In a study by Coskunseven et al. in $2008^{(30)}, 68 \%$ of 50 eyes exhibited improved corrected VA. The mean keratometry decreased from 50.6 D to 47.5 D, and the mean SE 


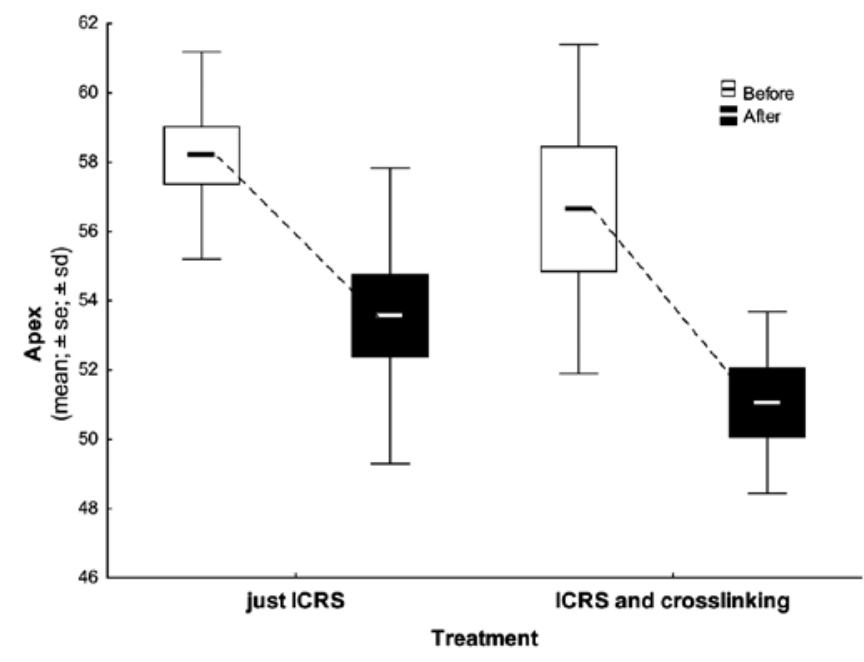

se $=$ standard error; $s d=$ standard deviation.

Figure 3. Pre and postoperative mean apex data per groups (diopters).

Table 5. Follow-up of the ICRS + crosslinking group after 3 months

\begin{tabular}{lccc}
\hline Variable & Pré & Pós $3 \mathbf{~ m}$ & P value* \\
\hline VA CC & $20.00 \pm 0$ & $20.00 \pm 0$ & - \\
VA logMAR pré & $0.56 \pm 0.34$ & $0.21 \pm 0.12$ & 0.007 \\
Spheric pré & $-4.45 \pm 2.18$ & $-2.33 \pm 3.13$ & 0.007 \\
Cilindric pré & $-4.93 \pm 1.03$ & $-2.30 \pm 1.88$ & 0.010 \\
SE pré & $-6.91 \pm 1.93$ & $-3.38 \pm 3.42$ & 0.002 \\
K-average pré & $47.20 \pm 2.10$ & $44.10 \pm 4.00$ & 0.088 \\
Apex pré & $56.90 \pm 4.40$ & $52.10 \pm 3.00$ & 0.006 \\
\hline
\end{tabular}

* $=$ paired Student's t-test, $p<0.05$.

decreased from -5.6 D to -2.4 D over a year. In our study, we observed an improvement in the corrected VA in $93.7 \%$ eyes. The mean keratometry decreased from 50.90 D to 47.12 D, and the mean SE decreased from -5.89 D to -2.65 D over a year in the group that also had ICRSI. When associated to $C X \mathrm{~L}$, the mean keratometry decreased from 47.06 D to 44.50 D, and the mean SE decreased from -6.91 D to -2.11 D during the same period. We also found two recipients in the group 1 that did not gain any lines of vision (in one case, the SE changed from $-5.00 \mathrm{D}$ to $-8.00 \mathrm{D}$; and in the other, the SE improved from -2.25 to $-0.5 \mathrm{D}$ with no gain in VA).

Kubaloglu et al. ${ }^{(29)}$ compared the manual technique with the femtosecond laser and reported a significantly higher rate of epithelial defects when using the manual technique (44\% vs. $14 \%)$. In this study, authors obtained similar refractive SE and VA results with both tunnel construction techniques and observed that the incidence of complications was significantly lower when using the femtosecond laser technique than that with the manual technique. Moreover, it has been confirmed that using laser for tunnel construction made the procedure easier, quicker, and more comfortable for the patient and surgeon and allowed a more precise corneal dissection at a predetermined depth ${ }^{(25,27)}$. In 2011, Coskunseven et al. described the occurrence of intraoperative complications during ring implantation in 850 eyes using femtosecond laser, including incomplete tunnel formation (2.6\%), galvanometer lag error due to system malfunction $(0.6 \%)$, endothelial perforation $(0.6 \%)$, incorrect entry into the tunnel $(0.2 \%)$, and loss of vacuum $(0.1 \%)$ as well as postoperative compli- cations, such as ring migration $(0.8 \%)$, corneal melting $(0.2 \%)$, and infection $(0.1 \%)^{(28)}$. In our study, no intraoperative or postoperative complications were observed, including in the group that also underwent CXL.

\section{CONCLUSION}

In summary, we observed a significant improvement in VA and refractive SE values, decreased curvature of the cone apex in the topographical analysis, and decreased corrected diopters postoperatively. ICRS implants do not ensure control of the ectasia and CXL does not affect visual outcomes in patients who underwent the ICRSI procedure. Furthermore, no postoperative complications were observed with the femtosecond laser and CXL procedures. Both techniques were safe and effective in reducing irregular astigmatism and myopia in patients with keratoconus.

\section{REFERENCES}

1. Krachmer JH, Feder RS, Belin MW. Keratoconus and related noninflammatory corneal thinning disorders. Surv Ophthalmol. 1984;28(4):293-322.

2. McDonald MB, Kaufman HE, Durrie DS, Keates RH, Sanders DR. Epikeratophakia for keratoconus. The nationwide study. Arch Ophthalmol. 1986;104(9):1294-300.

3. Koch DD. Refractive surgery for keratoconus: a new approach. J Cataract Refract Surg. 2000;26(8):1099-100.

4. Sekundo W, Stevens JD. Surgical treatment of keratoconus at the turn of the $20^{\text {th }}$ century. J Refract Surg. 2001;17(1):69-73.

5. Kanellopoulos AJ, Pe LH, Perry HD, Donnenfeld ED. Modified intracorneal ring segment implantations (INTACS) for the management of moderate to advanced keratoconus: efficacy and complications. Cornea. 2006;25(1):29-33.

6. Bourcier T, Borderie V, Laroche L. Late bacterial keratitis after implantation of intrastromal corneal ring segments. J Cataract Refract Surg. 2003;29(2):407-9

7. Ertan A, Bahadir M. Topography-guided vertical implantation of Intacs using a femtosecond laser for the treatment of keratoconus. J Cataract Refract Surg. 2007; 33(1):148-51.

8. Alió JL, Shabayek MH, Artola A. Intracorneal ring segments for keratoconus correction: long-term follow-up. J Cataract Refract Surg. 2006;32(6):978-85.

9. Burris TE, Ayer CT, Evensen DA, Davenport JM. Effects of intrastromal corneal ring size and thickness on corneal flattening in human eyes. Refract Corneal Surg. 1991; 7(1):46-50.

10. Alió $J L$, Artola A, Hassanein A, Haroun $H$, Galal A. One or 2 Intacs segments for the correction of keratoconus. J Cataract Refract Surg. 2005;31(5):943-53.

11. Tunc Z, Deveci N, Sener B, Bahcecioglu H. [Corneal ring segments (INTACS) for the treatment of asymmetrical astigmatism of the keratoconus. Follow-up after 2 years]. J Fr Ophthalmol. 2003;26(8):824-30. French.

12. Boxer Wachler BS, Christie JP, Chandra NS, Chou B, Korn T, Nepomuceno R. Intacs for keratoconus. Ophthalmology. 2003;110(5):1031-40.

13. Ruckhofer J, Stoiber J, Alzner E, Grabner G; Multicenter European Corneal Correction Assessment Study Group. One-year results of European multicenter study of intrastromal corneal ring segments. Part 2: complications, visual symptoms, and patient satisfaction. J Cataract Refract Surg. 2001;27(2):287-96.

14. Zadok D, Schwarts S, Marcovich A, Barkana Y, Morad Y, Eting E, et al. Penetrating keratoplasty for keratoconus: long-term results. Cornea. 2005;24(8):959-61.

15. Watson SL, Ramsay A, Dart JK, Bunce C, Craig E. Comparison of deep lamellar keratoplasty and penetrating keratoplasty in patients with keratoconus. Ophthalmology. 2004:111(9):1676-82

16. Buzard KA, Fundingsland BR. Corneal transplant for keratoconus: results in early and late disease. J Cataract Refract Surg. 1997;23(3):398-406.

17. Sharif KW, Casey TA. Penetrating keratoplasty for keratoconus: complication and longterm success. Br J Ophthalmology. 1991;75(3):142-6.

18. Tuft SJ, Gregory WM, Davison CR. Bilateral penetrating keratoplasty for keratoconus Ophthalmology. 1995;102(3):462-8.

19. Colin J, Cochener B, Savary G, Malet F. Correcting keratoconus with intracorneal rings. J Cataract Refract Surg. 2000;26(8):1117-22. Comment in: J Cataract Refract Surg. 2000;26(8):1099-100; J Cataract Refract Surg. 2001;27(3):341.

20. Lovisolo CF, Fleming JF. Intracorneal ring segment for iatrogenic keratectasia after laser in situ keratomileusis or photorefractive keratectomy. J Cataract Refract Surg. 2002;18(5):535-41.

21. Colin J, Cochener B, Savary G, Malet F, Holmes-Higgin D. INTACS inserts for treating keratoconus: one-year results. Ophthalmology. 2001;108(8):1409-14.

22. Ruckhofer J, Stoiber J, Alzner E, Grabner G; Multicenter European Corneal Correction Assessment Study Group. One year results of European multicenter study of intracorneal ring segments. Part 1: refractive outcomes. J Cataract Refract Surg. 2001; 27(2):277-86. 
23. Bourcier $T$, Borderie $V$, Laroche $L$. Late bacterial keratitis after implantation of intrastromal corneal ring segments. J Cataract Refract Surg. 2003;29(2):407-9.

24. Siganos CS, Kymionis GD, Kartakis N, Theodoraids MA, Theodorakis MA, Astyrakakis N, et al. Management of keratoconus with Intacs. Am J Ophthalmology. 2003;135(1):64-70.

25. Rabinowitz YS, Li X, Ignacio TS, Maguen E. INTACS inserts using the femtosecond laser compared to the mechanical spreader in the treatment of keratoconus. Cataract Refract Surg. 2008;22(8):764-71. Comment in: J Refract Surg. 2007;23(3):221-2; author reply 222

26. Ratkay-Traub I, Ferincz IE, Juhasz T, Kurtz RM, Krueger RR. First clinical results with the femtosecond neodynium-glass laser in refractive surgery. J Refract Surg. 2003; 19(2):94-103.

27. Kubaloglu A, Sari SE, Cinar Y, Cingu K, Koytak A, Coskun E, et al. Comparison of mecha- nical and femtosecond laser tunnel creation for intrastromal corneal ring segment implantation in keratoconus: prospective randomized clinical trial. J Cataract Refract Surg. 2010;36(9):1556-61.

28. Coskunseven E, Kymionis GD, Tsiklis NS, Atun S, Arslan E, Siganos CS, et al. Complications of intrastromal corneal ring segment implantation using a femtosecond laser for channel creation: a survey of 850 eyes with keratoconus. Acta Ophthalmol. 2011;89(1):54-7.

29. Ertan A, Colin J. Intracorneal rings for keratoconus and keratectasia. J Cataract Refract Surg. 2007;33(7):1303-14.

30. Haddad W, Fadlallah A, Dirani A, El Rami H, Fahd D, Khanafer D, et al. Comparison of 2 types of intrastromal corneal ring segments for keratoconus. J Cataract Refract Surg. 2012:38(7):1214-21.

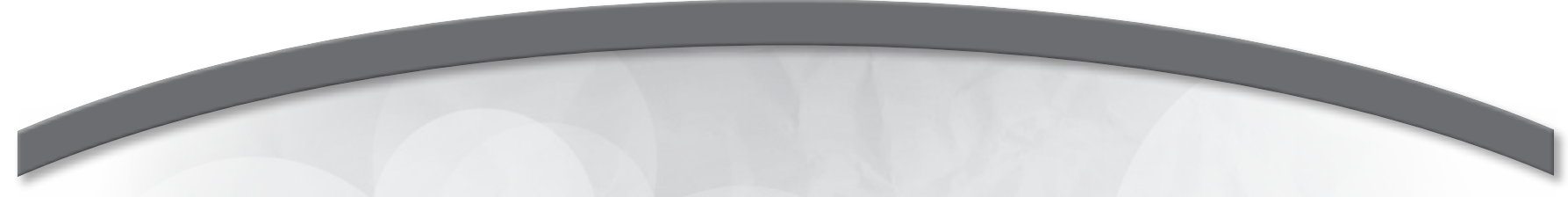

\title{
$40^{\circ}$ Congresso da Sociedade Brasileira de Retina e Vítreo
}

\author{
18 a 20 de abril de 2015
}

Costão do Santinho

Florianópolis - SC

\section{Informações:}

Site: www.retina2015.com.br

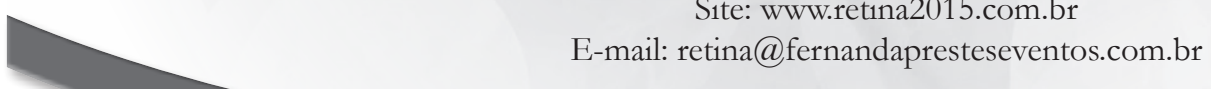

